\title{
PENERAPAN UJI STATISTIK MODEL LOG-LINEAR \\ DALAM MENGANALISIS KARAKTERISTIK MAHASISWA \\ UNIVERSITAS TERBUKA UPBJJ MEDAN
}

\author{
Sondang Purnama Sari Pakpahan \\ sondangp@ut.ac.id
}

\begin{abstract}
Abstrak
Penelitian ini bertujuan untuk: mengetahui dimensi karakteristik mahasiswa Universitas Terbuka UPBJJ Medan, mengetahui dimensi karakteristik mahasiswa UT UPBJJ Medan yang cenderung menimbulkan dependensi, dan menentukan model matematika yang sesuai untuk dependensi multivariable.

Rancangan yang digunakan dalam penelitian ini adalah Model Log Linear. Alasannya adalah karena data penelitian ini berupa data kategorikal yang bersifat diskrit, sehingga dapat dilakukan uji independensi antar variabel, untuk menemukan besarnya interaksi yang menyebabkan variabel tersebut dependen.

Dengan analisis log linear dihasilkan model, yaitu terdapat hubungan dan interaksi antara jenis kelamin, cara belajar, IPK, antara cara belajar dan IPK, antara pendidikan terakhir dan alasan masuk UT, antara pendidikan terakhir dan IPK, antara status pernikahan dan IPK, antara tempat tinggal dan IPK, antara tempat tinggal dan keikutsertaan dalam tutorial tatap muka, antara tempat tinggal dan keikutsertaan dalam tutorial on-line dan IPK.
\end{abstract}

\section{Kata Kunci: Karakteristik mahasiswa, Model Log Linear, mahasiswa UT}

\section{PENDAHULUAN}

$$
\text { Universitas Terbuka }
$$

merupakan Perguruan Tinggi Terbuka dan Jarak Jauh (PTJJ). Terbuka menunjukkan bahwa tidak ada batasan usia, tahun ijazah, dan masa belajar di UT. Batasan yang ada hanyalah bahwa setiap mahasiswa UT harus sudah menamatkan jenjang pendidikan menengah (SMA atau sederajat). Jarak Jauh menunjukkan pembelajaran tidak dilakukan secara tatap muka melainkan melalui mediasi bahan ajar, baik cetak maupun non-cetak.
Berdasarkan pengertian Terbuka dan Jarak Jauh ini dapat diduga bahwa mahasiswa UT memiliki karakteristik yang berbeda dengan mahasiswa pada perguruan tinggi tatap muka biasa, baik pada latar belakang maupun pada cara belajar dan motivasi belajar.

Saat ini Universitas Terbuka memiliki 578.698 mahasiswa aktif yang tersebar di 37 Unit Program Belajar Jarak Jauh (UPBJJ) di seluruh Indonesia (Data per 30 November 2011, sumber data

Penerapan Uji Statistik Model Log-Linear Dalam Menganalisis - 10 
http://www.ut.ac.id). UPBJJ-UT Medan dengan rincian 1.381 mahasiswa program non pendidikan dasar dan 15.590 mahasiswa pendidikan dasar (data per 29 Februari 2012). Penelitian tentang karakteristik mahasiswa suatu perguruan tinggi adalah penting karena mahasiswa adalah objek yang akan menerima program kerja, sasaran, dan layanan akademik maupun non-akademik. Dengan mengetahui karakteristik mahasiswa maka program kerja, sasaran, dan layanan mahasiswa diharapkan akan efektif dan efisien.

Artikel ini akan menyajikan hasil penelitian tentang "Penerapan Uji Statistik Model Log Linear Dalam Menganalisis Karakteristik Mahasiswa Universitas Terbuka UPBJJ Medan" Beberapa penelitian mengenai penerapan analisis model log linear telah dilakukan. Pujiti (2008) menerapkan analisis model log linear untuk mengetahui hubungan antara status sekolah, jumlah guru berpendidikan S1, dan angka mengulang pada siswa SD. Tabel kontingensi dan Log Linear pada penelitian ini menghasilkan gambaran mengenai adanya hubungan antara status sekolah, prosentase guru berpendidikan minimal Sarjana, dan angka mengulang pada siswa SD. Rosalia dkk (2011) juga meneliti kecenderungan karakteristik anak saat ini memiliki 16.971 mahasiswa jalanan binaan di Surabaya berdasarkan faktor sosial ekonomi dan perilaku anak jalanan dengan menggunakan analisis model log linear. Penelitian Rosalia menghasilkan model yaitu terdapat hubungan antara kegiatan anak di jalan dengan keterlibatan konflik dengan aparat pemerintah, lama menjadi anak jalanan dengan harapan terhadap pemerintah, hubungan sosial dalam keluarga dengan frekuensi kunjungan ke rumah singgah, faktor penyebab menjadi anak jalanan dengan keterlibatan konflik dengan masyarakat, dan kondisi lingkungan tempat tinggal dengan frekuensi ke rumah singgah.

Perbedaan kedua penelitian diatas dengan penelitian pada artikel ini adalah pada fokus penelitian. Pada artikel ini fokus penelitian adalah karakteristik mahasiswa UPBJJ UT Medan yang meliputi tiga dimensi yaitu: (1) dimensi latar belakang mahasiswa (2) dimensi motivasi belajar, dan (3) prestasi belajar. Analisis model loq linear yang digunakan adalah model log linear tiga dimensi yang berbentuk :

$$
\log e_{i j}=\mathrm{u}+u_{1(\mathrm{i})}+u_{2(\mathrm{j})}+\mathrm{u}_{3(\mathrm{k})}
$$

Apabila variabel 1, 2 dan 3 ada dalam model, tapi tidak ada interaksi antara

Penerapan Uji Statistik Model Log-Linear Dalam Menganalisis -11 
ketiganya (ketiga variabel independen).

Jika terdapat interaksi pada ketiga

dimana :

$$
\begin{aligned}
& \mathrm{I}_{\mathrm{i}=1} \quad \mathrm{j}_{\mathrm{j}=1} u_{12} i j=\mathrm{I}_{\mathrm{i}=1}^{\mathrm{I}} \quad \mathrm{K}=1_{13(i k i)}= \\
& { }_{\mathrm{j}=1}^{\mathrm{J}} \quad \mathrm{k}=1 u_{23(j k)}= \\
& \mathrm{I}_{\mathrm{i}=1} \mathrm{~J}_{\mathrm{j}=1}^{\mathrm{K}} \quad \mathrm{K}=1_{123(i j k)}=0
\end{aligned}
$$

Sampel dalam penelitian yang dibahas ini adalah mahasiswa Non Pendidikan Dasar Universitas Terbuka UPBJJ Medan yang telah melakukan registrasi minimal 2 semester pada masa registrasi 2012.1. Diharapkan dalam waktu sekurang-kurangnya 2 semester mahasiswa telah memanfaatkan layanan bantuan belajar dan dapat dihitung Indeks Prestasi Kumulatif (IPK) nya. Dalam menentukan ukuran sampel digunakan rumus Slovin dengan $\mathrm{N}=1381$, e=0,05. variabel, maka model menjadi

$$
\begin{aligned}
& \log e_{i j k}=u+u_{1(i)}+u_{2(j)}+u_{3(k)}+ \\
& u_{12(i j)}+u_{13(i k)}+u_{23(j k)}+u_{123(i j k)}
\end{aligned}
$$

Diperoleh ukuran sampel 310. Adapun pengambilan sampel menggunakan metode purposive sampling, yaitu pemilihan sampel didasarkan pada kriteria-kriteria tertentu yang dibuat sesuai dengan tujuan penelitian. kriteria tersebut adalah (1) Mahasiswa Aktif Program Non Pendas, (2) Telah menyelesaikan studi min 2 semester (3) Belum pernah mengambil Cuti Akademik. Sebanyak 310 kuesioner didistribusikan ke tujuh lokasi ujian non pendas : (1) Medan, (2) Pematang Siantar, (3) Dairi, (4) Sibolga, (5)

\begin{tabular}{|c|c|c|}
\hline Dimensi & Variabel & Kategori \\
\hline Latar Belakang & a. Jenis Kelamin & 2. Perempuan \\
\hline \multirow[t]{5}{*}{ Mahasiswa } & a. Usia & 2. $23-30 \quad 3 .>30$ \\
\hline & b. Pendidikan Terakhir & 2. D1,D2, D3 \\
\hline & c. Status Pekerjaan & 2. Tidak Bekerja \\
\hline & d. Status Pernikahan & 2. Belum Menikah \\
\hline & e. Tempat tinggal & 1.Kota $/ \mathrm{Kab}$ 2. Kec/Desa \\
\hline \multirow[t]{7}{*}{ Motivasi } & a.Alasan Memilih UT & \multirow{4}{*}{$\begin{array}{l}\text { 1.Daripada tidak kuliah } \\
\text { 2.Dorongan Keluarga } \\
\text { 3. Tempat tinggal di pelosok, tidak ada PTN/PTS } \\
\text { 4. Tidak mengganggu pekerjaan }\end{array}$} \\
\hline & & \\
\hline & & \\
\hline & & \\
\hline & b.Tujuan masuk UT & \multirow{3}{*}{$\begin{array}{l}\text { 1.Memperoleh ijazah Sarjana } \\
\text { 2.Menambah ilmu pengetahuan } \\
\text { 3.Meningkatkan karir }\end{array}$} \\
\hline & & \\
\hline & & \\
\hline
\end{tabular}
Gunung Sitoli, (6) Idanogawo, (7) Teluk Dalam. Kuesioner berisi pertanyaan yang dikembangkan dari kisi-kisi instrumen penelitian, yaitu:

Penerapan Uji Statistik Model Log-Linear Dalam Menganalisis -12 


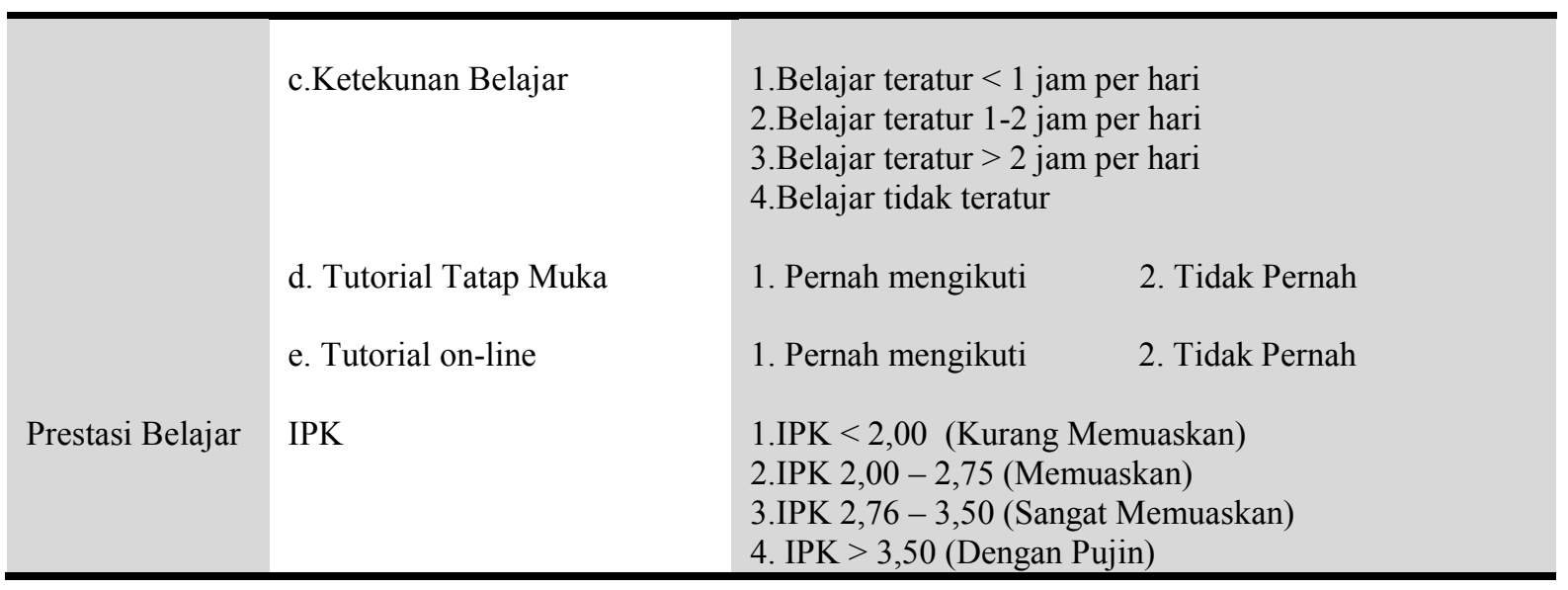

Dari 310 kuesioner yang didistribusikan hanya 200 kuesioner yang kembali dari hanya 151 kuesioner yang memenuhi kriteria untuk diteliti. Sesuai dengan tujuan penelitian ini, maka teknik analisis data yang digunakan adalah Model Log Linear. Alasannya adalah karena data penelitian ini berupa data kategorikal yang bersifat diskrit, sehingga dapat dilakukan uji independensi antar variabel, dan untuk menemukan besarnya interaksi yang menyebabkan variabel tersebut dependen.

\section{HASIL DAN PEMBAHASAN}

Untuk mengetahui karakteristik mahasiswa non pendas UPBJJ UT Medan maka digambarkan pada tabel dibawah ini

Tabel 1. Karakteristik Mahasiswa Non Pendas UPBJJ UT Medan

\begin{tabular}{|c|c|c|c|}
\hline Variabel & Kategori & Frekuensi & Persentase \\
\hline \multirow{2}{*}{ Jenis Kelamin } & Pria & 83 & 65 \\
\hline & Wanita & 68 & 45 \\
\hline \multirow{3}{*}{ Usia } & $19-22$ & 32 & 21,2 \\
\hline & $23-30$ & 82 & 54,3 \\
\hline & $>30$ & 37 & 24,5 \\
\hline \multirow{2}{*}{ Pendidikan Terakhir } & SLTA & 119 & 78,8 \\
\hline & D1,D2,D3 & 32 & 21,2 \\
\hline \multirow[t]{2}{*}{ Pekerjaan } & Bekerja & 121 & 80,1 \\
\hline & Tidak Bekerja & 30 & 19,9 \\
\hline \multirow{2}{*}{ Status Pernikahan } & Menikah & 68 & 45 \\
\hline & Tidak Menikah & 83 & 55 \\
\hline \multirow{2}{*}{ Tempat Tinggal } & Kota/Kab & 60 & 39,7 \\
\hline & Kec/desa & 91 & 60,3 \\
\hline \multirow{4}{*}{ Alasan Memilih UT } & Daripada tidak kuliah & 19 & 12,6 \\
\hline & Dorongan Keluarga & 11 & 7,3 \\
\hline & $\begin{array}{l}\text { Tempat tinggal di pelosok, tidak ada } \\
\text { PTN/PTS }\end{array}$ & 17 & 11,3 \\
\hline & Tidak mengganggu pekerjaan & 104 & 68,9 \\
\hline
\end{tabular}




\begin{tabular}{|c|c|c|c|}
\hline \multirow{3}{*}{ Tujuan masuk UT } & Memperoleh ijazah Sarjana & 17 & 11,3 \\
\hline & Menambah ilmu pengetahuan & 83 & 55 \\
\hline & Meningkatkan karir & 50 & 33.1 \\
\hline \multirow{4}{*}{ Ketekunan Belajar } & Belajar teratur $<1$ jam per hari & 29 & 19,2 \\
\hline & .Belajar teratur 1-2 jam per hari & 32 & 21,2 \\
\hline & Belajar teratur $>2$ jam per hari & 10 & 6,6 \\
\hline & Belajar tidak teratur & 80 & 53 \\
\hline \multirow{2}{*}{ Tutorial Tatap Muka } & Pernah Mengikuti & 26 & 17,2 \\
\hline & Tidak Pernah Mengikuti & 125 & 82,8 \\
\hline \multirow[t]{2}{*}{ Tutorial on-line } & Pernah Mengikuti & 54 & 35,8 \\
\hline & Tidak Pernah Mengikuti & 97 & 64,2 \\
\hline \multirow{4}{*}{ IPK } & .IPK $<2,00$ (Kurang Memuaskan) & 84 & 55,6 \\
\hline & IPK 2,00 - 2,75 (Memuaskan) & 51 & 33,8 \\
\hline & $\begin{array}{l}\text { IPK 2,76 - 3,50 (Sangat } \\
\text { Memuaskan) }\end{array}$ & 15 & 9,9 \\
\hline & IPK $>3,50$ (Dengan Pujin) & 1 & 0,7 \\
\hline
\end{tabular}

Sumber: Data Diolah

Dari tabel diatas terlihat bahwa karakteristik mahasiswa UT UPBJJ Medan cenderung :berjenis kelamin pria, rentang usia 23-30 tahun, pendidikan terakhir SLTA, status bekerja, tidak menikah, tinggal dikecamatan atau desa, alasan memilih UT karena tidak menganggu pekerjaan, tujuan masuk UT untuk menambah pengetahuan, belajar tidak teratur, tidak pernah mengikuti tutorial tatap muka, cenderung tidak pernah mengiktui tutorial online dan IPK $<2,00$. Karakteristik ini sesuai dengan hasil penelitian Sireagar (2002) yang menyatakan bahwa mayoritas mahasiswa UT adalah laki-laki, berstatus tidak kawin, sebahagian besar mahasiswa bekerja, dan berijazah SLTA.
Berikut ini akan disajikan hasil pengujian interaksi pada derajat $\mathrm{K}$ dan lebih tinggi sama dengan nol, dan pengujian interaksi pada derajat $\mathrm{K}$ sama dengan nol untuk masing-masing indikator.

\section{A. Hubungan Antara Jenis Kelamin, Alasan Masuk UT, dan IPK}

Dari hasil pengujian hipotesis tentang parameter pengaruh $\mathrm{k}$ - Arah dan orde lebih tinggi ( test that $k$-way and higher order effects are zero) untuk variabel jenis kelamin, alasan masuk UT, dan IPK, terlihat pada Tabel 2 bahwa pada $\mathrm{K}=1$ diperoleh

$$
G^{2}(o, \text { ooo })<\alpha=0,05
$$

,(signifikan pada $\alpha=0,05$ ) yang berarti ada efek interaksi satu variabel atau lebih dalam model. 
Tabel 2. Uji K-Arah Hubungan Antara Jenis Kelamin Alasan Masuk UT Dan IPK K-Way and Higher-Order Effects

\begin{tabular}{|ll|l|l|l|l|l|l|}
\hline & \multirow{3}{*}{$\mathrm{K}$} & $\mathrm{jf}$ & \multicolumn{2}{|l|}{ Likelihood Ratio } & Pearson & Number of \\
\cline { 5 - 8 } & & Chi-Square & Sig. & Chi-Square & Sig. & Iterations \\
\hline K-way and Higher & 1 & 31 & 282.109 & .000 & 378.166 & .000 & 0 \\
Order Effects $^{\mathrm{a}}$ & 2 & 24 & 20.062 & .693 & 18.461 & .780 & 2 \\
& 3 & 9 & 6.618 & .677 & 5.576 & .781 & 3 \\
\hline K-way Effects $^{\mathrm{b}}$ & 1 & 7 & 262.047 & .000 & 359.705 & .000 & 0 \\
& 2 & 15 & 13.444 & .568 & 12.885 & .611 & 0 \\
& 3 & 9 & 6.618 & .677 & 5.576 & .781 & 0 \\
\hline
\end{tabular}

Sumber : Data Diolah

Selanjutnya seleksi model dilakukan dengan metode backward, dimana penyelesaiannya dimulai dari model yang paling lengakp terlebih dahulu kemudian diadakan pengujian efek demi efek dalam model, dan apabila suatu unsur tertentu ternyata probabilitas $>\alpha=0,05$, maka unsur tersebut harus dikeluarkan dari model karena tidak signifikan. Demikian seterusnya hingga diperoleh model terbaiknya. Dari hasil seleksi model diperoleh model terbaik adalah :

$$
\log e_{i j k}=U+U_{1(i)}+U_{2(j)}+U_{3(k)}+U_{23(j k)}
$$

Berikutnya dilakukan uji parsial untuk menguji apakah sesuatu variabel signifikan didalam model. Dari hasil uji parsial untuk variabel jenis kelamin, alasan masuk UT, dan IPK diperoleh nilai statistik Khi Kuadrat parsial sebesar masing-masing > 0,05, maka hipotesis nol diterima (lihat Tabel 3). Hal ini berarti tidak ada hubungan atau interaksi antara jenis kelamin dengan alasan masuk UT dengan IPK. Dari data terlihat bahwa jenis kelamin laki-laki maupun perempuan dengan alasan masuk UT tidak mengganggu pekerjaan memiliki IPK $<2$.

Tabel.3 Hasil Uji Parsial Antara Jenis Kelamin Dengan Alasan Masuk UT Dengan IPK

\begin{tabular}{|l|c|c|c|c|}
\hline Faktor & df & $\chi^{2}$ Parsial & Signifikan & Jumlah iterasi \\
\hline Jenis Kelamin dengan alasan masuk UT & 3 & 2.376 & 0.498 & 2 \\
\hline Jenis kelamin dengan IPK & 3 & 1.754 & 0.625 & 2 \\
\hline Alasan masuk UT dengan IPK & 9 & 9.532 & 0.390 & 2 \\
\hline
\end{tabular}

Sumber : Data Diolah 


\section{B. Hubungan Antara Jenis Kelamin, Tujuan Masuk UT Dan IPK}

Dengan cara yang sama, diperolehi hasil pengujian hipotesis tentang parameter pengaruh $\mathrm{k}$ - Arah dan orde lebih tinggi ( test that $k-w a y$ and higher order effects are zero) untuk variabel jenis kelamin, tujuan masuk UT, dan IPK, yaitu pada $\mathrm{K}=1 \quad$ diperoleh $\quad G^{2}(o, o o o)<\alpha=0,05$ ,(signifikan pada $\alpha=0,05$ ) yang berarti ada efek interaksi satu variabel atau lebih dalam model. Selanjutnya, dalam seleksi model untuk menentukan model terbaik diperoleh diperoleh model terbaik adalah :

$$
\log e_{i j k}=U+U_{1(i)}+U_{2(j)}+U_{3(k)}+U_{23(j k)}
$$

Namun alam uji asosiasi parsial, diperoleh hasil masing2 nilai signifikansi
> 0,05 yang berarti Ho diterima dan hubungan antara jenis kelamin dengan tujuan masuk UT, Jenis kelamin dengan IPK, tujuan masuk UT dengan IPK tidak dipakai dalam model.

\section{Hubungan Jenis Kelamin Dengan Cara Belajar Dan IPK}

Dari hasil pengujian hipotesis tentang parameter pengaruh $\mathrm{k}$ - Arah dan orde lebih tinggi ( test that $k$-way and higher order effects are zero) untuk variabel jenis kelamin, Cara Belajar di UT, dan IPK, terlihat pada Tabel 4 bahwa pada $\mathrm{K}=1 \quad$ dan $\quad 2 \quad$ diperoleh $G^{2}(o, o o o)<\alpha=0,05$, (signifikan pada $\alpha$ $=0,05)$ yang berarti ada efek interaksi satu variabel atau lebih dalam model.

Tabel 4. Uji K-Arah Hubungan Antara Jenis Kelamin, Cara Belajar, dan Dan IPK K-Way and Higher-Order Effects

\begin{tabular}{lrrrrrrr}
\hline & \multicolumn{4}{c}{ Likelihood Ratio } & \multicolumn{2}{c}{ Pearson } & \multicolumn{2}{c}{ Number of } \\
& $\mathrm{K}$ & df & Chi-Square & Sig. & Chi-Square & Sig. & Iterations \\
K-way and Higher Order & 1 & 31 & 230.550 & .000 & 253.556 & .000 & 0 \\
Effects $^{\mathrm{a}}$ & 2 & 24 & 31.222 & .147 & 54.298 & .000 & 2 \\
K-way Effects $^{\mathrm{b}}$ & 3 & 9 & 4.383 & .884 & 4.196 & .898 & 4 \\
& 1 & 7 & 199.328 & .000 & 199.258 & .000 & 0 \\
& 2 & 15 & 26.839 & .030 & 50.102 & .000 & 0 \\
& 3 & 9 & 4.383 & .884 & 4.196 & .898 & 0 \\
\hline
\end{tabular}

Sumber : Data Diolah

Penerapan Uji Statistik Model Log-Linear Dalam Menganalisis - 16 
Selanjutnya, dalam seleksi model perguruan tinggi dipengaruhi oleh untuk menentukan model terbaik diperoleh beberapa faktor diantaranya jenis kelamin diperoleh model terbaik adalah : dan status pernikahan. Hasil juga sesuai

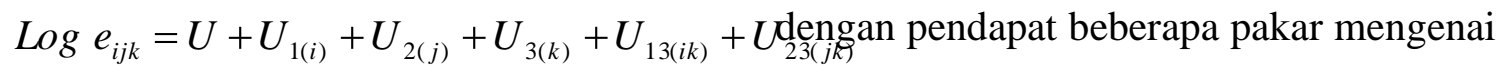
motivasi belajar yang menyatakan bahwa

Dalam uji asosiasi parsial diketahui adanya interaksi antara variabel jenis kelamain (V1) dan IPK (V12) serta antara variabel cara belajar (V9) dan IPK (V12) (Lihat Tabel 5). Hasil penelitian sesuai dengan penelitian terdahulu yang dilakukan oleh Brahmantio tahun 2003 yang menemukan bahwa prestasi mahasiswa pascasarjana di suatu motivasi belajar akan menentukan ketekunan dan cara belajar siswa dengan motivasi belajar yang tinggi akan memperoleh prestasi belajar yang lebih baik (Fadloli, 2011). Hawley dalam Yusuf (1993) menyatakan bahwa para siswa yang memiliki motivasi tinggi lebih baik dibandingkan siswa yang motivasi belajarnya rendah.).

\section{Tabel.5 Hasil Uji Parsial Antara Jenis Kelamin Dengan Cara Belajar Dengan IPK}

\section{Partial Associations}

\begin{tabular}{lrrrr}
\hline & & & \multicolumn{2}{c}{ Number of } \\
Effect & df & Partial Chi-Square & Sig. & Iterations \\
VAR00001*VAR00012 & 3 & 4.129 & .248 & 2 \\
VAR00001*VAR00009 & 3 & 8.059 & .045 & 2 \\
VAR00012*VAR00009 & 9 & 19.620 & .020 & 2 \\
VAR00001 & 1 & 1.493 & .222 & 2 \\
VAR00002 & 3 & 130.107 & .000 & 2 \\
VAR000093 & 3 & 67.729 & .000 & 2 \\
\hline
\end{tabular}

Sumber : Data Diolah

\section{Hubungan antara Jenis Kelamin,}

\section{Tutorial Tatap Muka dan IPK}

Dengan cara yang sama, diperolehi hasil pengujian hipotesis tentang parameter pengaruh $\mathrm{k}$ - Arah dan orde lebih tinggi ( test that $k$-way and higher order effects are zero) untuk variabel jenis kelamin, tujuan masuk UT, dan IPK, yaitu pada
$\mathrm{K}=1 \quad$ diperoleh $\quad G^{2}(o, o o o)<\alpha=0,05$ ,(signifikan pada $\alpha=0,05$ ) yang berarti ada efek interaksi satu variabel atau lebih dalam model. Selanjutnya, dalam seleksi model untuk menentukan model terbaik diperoleh diperoleh model terbaik adalah :

$$
\log e_{i j k}=U+U_{1(i)}+U_{2(j)}+U_{3(k)}+U_{23(j k)}
$$


Namun dalam uji asosiasi parsial, diperoleh hasil masing2 nilai signifikansi $>0,05$ yang berarti Ho diterima dan tidak ada interaksi antara jenis kelamin * tatap muka, Jeinis kelamin * IPK, tutorial tatap muka * IPK. Dari data terlihat bahwa jenis kelamin laki-laki dan perempuan dan tidak pernah mengikuti tutorial tatap muka, memiliki IPK $<2$.

\section{E. Hubungan Jenis Kelamin Dengan} Tutorial Online Dan IPK

Dari hasil analisis juga ditemukan hipotesis nol diterima. Hal ini berarti tidak ada interaksi antara jenis kelamin dengan tutorial online, jenis kelamin dengan IPK, tutorial online dan IPK. Dari data terlihat, jenis kelamin laki-laki maupun perempuan dan tidak pernah mengikuti tutorial online memiliki IPK $<2$.

\section{F. Hubungan Antara Usia Dengan} Alasan Masuk UT Dengan IPK

Dari hasil analisis juga ditemukan hipotesis nol diterima. Hal ini berarti tidak ada interaksi antara usia dengan alasan masuk UT, Usia dengan IPK, Alasan masuk UT dengan IPK. Data menunjukkan usia 19-22, 23-30, >30 dengan alasan masuk UT tidak menggangu pekerjaan, memiliki IPK $<2$.

\section{G. Hubungan Usia Dengan Tujuan Masuk UT Dengan IPK}

Dari hasil analisis juga ditemukan hipotesis nol diterima. Hal ini berarti tidak ada interaksi antara usia dengan tujuan masuk UT, Usia dengan IPK, tujuan masuk UT dengan IPK. Data menunjukkan usia 19-22, 23-30, >30, dengan tujuan masuk UT dengan tujuan menambah ilmu pengetahuan, memiliki IPK $<2$.

\section{H. Hubungan Usia dengan Cara Belajar dengan IPK \\ Dari hasil pengujian hipotesis} tentang parameter pengaruh $\mathrm{k}-$ Arah dan orde lebih tinggi ( test that $k-$ way and higher order effects are zero) untuk variabel usia, Cara Belajar di UT, dan IPK, terlihat pada Tabel 6 bahwa pada $\mathrm{K}=1$ dan 2 diperoleh $G^{2}(o$, ooo $)<\alpha=0,05$ ,(signifikan pada $\alpha=0,05)$ yang berarti ada efek interaksi satu variabel atau lebih dalam model. 
Tabel 6. Uji K-Arah Hubungan Antara Usia, Cara Belajar, dan Dan IPKK-Way and

\section{Higher-Order Effects}

\section{K-Way and Higher-Order Effects}

\begin{tabular}{llrrrrrr}
\hline & \multicolumn{6}{c}{ Likelihood Ratio } & \multicolumn{2}{c}{ Pearson } & \\
& $\mathrm{K}$ & df & Chi-Square & Sig. & Chi-Square & Sig. & Number of Iterations \\
K-way and Higher Order & 1 & 47 & 277.452 & .000 & 361.742 & .000 & 0 \\
Effects $^{\mathrm{a}}$ & 2 & 39 & 51.337 & .089 & 67.183 & .003 & 2 \\
K-way Effects $^{\mathrm{b}}$ & 3 & 18 & 15.484 & .629 & 14.035 & .727 & 4 \\
& 1 & 8 & 226.115 & .000 & 294.559 & .000 & 0 \\
& 2 & 21 & 35.853 & .023 & 53.148 & .000 & 0 \\
& 3 & 18 & 15.484 & .629 & 14.035 & .727 & 0 \\
\hline
\end{tabular}

Sumber : Data Diolah

Selanjutnya, dalam seleksi model untuk menentukan model terbaik diperoleh diperoleh model terbaik adalah :

$$
\log e_{i j k}=U+U_{1(i)}+U_{2(j)}+U_{3(k)}+U_{23(j k)}
$$

Dalam uji asosiasi parsial diketahui adanya interaksi antara cara belajar (V9) dan IPK (V12) (Lihat Tabel 7)

\section{Tabel 7. Hasil Uji Parsial Antara Usia Dengan Cara Belajar Dengan IPK}

\begin{tabular}{lrcrr}
\multicolumn{5}{c}{ Partial Associations } \\
\hline \\
Effect & Df & $\begin{array}{c}\text { Partial Chi- } \\
\text { Square }\end{array}$ & \multicolumn{1}{c}{ Sig. } & Number of \\
VAR00002*VAR00012 & 6 & 9.176 & .164 & 2 \\
VAR00002*VAR00009 & 6 & 10.062 & .122 & 2 \\
VAR00012*VAR00009 & 9 & 17.657 & .039 & 2 \\
VAR00002 & 2 & 28.279 & .000 & 2 \\
VAR00012 & 3 & 130.107 & .000 & 2 \\
VAR00009 & 3 & 67.729 & .000 & 2 \\
\hline
\end{tabular}

Sumber : Data Diolah

Hal ini berarti ada hubungan dan interaksi cara belajar dengan IPK. Hasil ini sesuai dengan penelitian terdahulu yang dilakukan oleh Hidayati ( 2012 ) dan Arifin (2012). Hidayati (2012) menemukan adanya hubungan yang positif dan signifikan antara cara belajar dengan prestasi belajar siswa kelas XII Jurusan
Pemasaran pada mata diklat melaksanakan proses administrasi transaksi. Arifin (2012) juga menemukan adanya korelasi yang positif dan kuat $(r=0,842)$ antara kebiasaan belajar di rumah dengan prestasi belajar siswa kelas VII B SMPN 13 Malang. 
I. Hubungan antara Usia dengan

\section{Tutorial Tatap Muka dengan IPK}

Dari hasil analisis juga ditemukan hipotesis nol diterima. Hal ini berarti tidak ada interaksi antara usia dengan tutorial tatap muka dengan IPK. Data menunjukkan usia 19-22, 23-30, >30, dan tidak pernah mengikuti tutorial tatap muka memiliki IPK $<2$.

\section{J. Hubungan antara Usia dengan Tutorial Online dengan IPK}

Dari hasil analisis juga ditemukan hipotesis nol diterima. Hal ini berarti tidak ada interaksi antara usia dengan tutorial on-line dengan IPK. Data menunjukkan usia 19-22, 23-30, >30 dan tidak pernah mengikuti tutorial online memiliki IPK < 2.

\section{K. Hubungan Antara Pendidikan Terakhir dengan Alasan Masuk UT dengan IPK}

Dengan cara yang sama, diperolehi hasil pengujian hipotesis tentang parameter pengaruh $\mathrm{k}$ - Arah dan orde lebih tinggi ( test that $k$-way and higher order effects are zero) untuk variabel pendidikan terakhir, alasan masuk UT, dan IPK, yaitu pada $\mathrm{K}=1$ diperoleh $G^{2}(o, o o o)<\alpha=0,05$ ,(signifikan pada $\alpha=0,05$ ) yang berarti ada efek interaksi satu variabel atau lebih dalam model. Selanjutnya, dalam seleksi model untuk menentukan model terbaik diperoleh diperoleh model terbaik adalah :

$$
\begin{aligned}
\text { Log } e_{i j k}=U+U_{1(i)}+U_{2(j)}+U_{3(k)}+U_{12(i j)} \\
\text {. Dalam uji asosiasi parsial, }
\end{aligned}
$$
ditemukan adanya interaksi antara variabel pendidikan terakhir (V3) dengan variabel alasan masuk UT (V7) dengan signifikansi $0,010<\alpha=0,05$ (lihat Tabel 8).

Tabel 8. Hasil Uji Parsial Antara Pendidikan Terakhir dengan Alasan Masuk UT dengan IPK

\section{Partial Associations}

\begin{tabular}{lrrrr}
\hline & \multicolumn{2}{c}{ Partial Chi- } & \multicolumn{2}{c}{ Number of } \\
Effect & df & Square & \multicolumn{1}{c}{ Sig. } & Iterations \\
VAR00003*VAR00007 & 3 & 11.307 & .010 & 2 \\
VAR00003*VAR00012 & 3 & 4.886 & .180 & 2 \\
VAR00007*VAR00012 & 9 & 8.115 & .523 & 2 \\
VAR00003 & 1 & 53.350 & .000 & 2 \\
VAR00007 & 3 & 130.447 & .000 & 2 \\
VAR00012 & 3 & 130.107 & .000 & 2 \\
\hline
\end{tabular}

Sumber : Data Diolah

Penerapan Uji Statistik Model Log-Linear Dalam Menganalisis -20 


\section{Hubungan Antara Pendidikan}

Terakhir Dengan tujuan Masuk UT Dengan IPK

Dari hasil analisis juga ditemukan hipotesis nol diterima. Hal ini berarti tidak ada interaksi antara pendidikan terakhir dengan tujuan masuk UT dengan IPK. Data menunjukkan bahwa:

1. Pendidikan terakhir SLTA dengan tujuan masuk UT menambah ilmu pengetahuan memiliki IPK $<2$

2. Pendidikan terakhir D1,D2,D3 dengan tujuan masuk UT meningkatkan karier memiliki IPK $2,75-3$

\section{Hubungan Antara Pendidikan Terakhir dan Cara Belajar Dengan IPK}

Dari hasil analisis juga ditemukan hipotesis nol diterima. Hal ini berarti tidak ada interaksi antara pendidikan terakhir dengan cara belajar dengan IPK.

\section{N. Hubungan Antara Pendidikan Terakhir Dengan Tutorial Tatap Muka dan IPK}

Dari hasil analisis juga ditemukan hipotesis nol diterima. Hal ini berarti tidak ada interaksi antara pendidikan terakhir dengan tutorial tatap muka dengan IPK.

\section{O. Hubungan Antara Pendidikan Terakhir Dengan Tutorial Online Dengan IPK}

Dari hasil pengujian hipotesis tentang parameter pengaruh $\mathrm{k}$ - Arah dan orde lebih tinggi ( test that $k-$ way and higher order effects are zero) untuk variabel Pendidikan Terakhir, Tutorial on-line, dan IPK, terlihat pada Tabel 9 bahwa pada $\mathrm{K}=1 \quad$ diperoleh $\quad G^{2}(o, o o o)<\alpha=0,05$ ,(signifikan pada $\alpha=0,05$ ) yang berarti ada efek interaksi satu variabel atau lebih dalam model. 
Tabel 9. Uji K-Arah Hubungan Antara Pendidikan Terakhir, Tutorial on-line, dan IPK KWay and Higher-Order Effects

K-Way and Higher-Order Effects

\begin{tabular}{llrrrrrr}
\hline & \multicolumn{6}{c}{ Likelihood Ratio } & \multicolumn{2}{c}{ Pearson } & \multicolumn{2}{c}{ Number of } \\
& $\mathrm{K}$ & \multicolumn{1}{c}{ df } & Chi-Square & \multicolumn{1}{c}{ Sig. } & Chi-Square & \multicolumn{1}{l}{ Sig. } & \multicolumn{1}{c}{ Iterations } \\
K-way and Higher & 1 & 31 & 434.422 & .000 & 775.728 & .000 & 0 \\
Order Effects $^{\mathrm{a}}$ & 2 & 24 & 29.218 & .212 & 31.653 & .136 & 2 \\
& 3 & 9 & 6.211 & .719 & 7.154 & .621 & 3 \\
K-way Effects $^{\mathrm{b}}$ & 1 & 7 & 405.204 & .000 & 744.075 & .000 & 0 \\
& 2 & 15 & 23.007 & .084 & 24.499 & .057 & 0 \\
& 3 & 9 & 6.211 & .719 & 7.154 & .621 & 0 \\
\hline
\end{tabular}

Sumber : Data Diolah

Selanjutnya, dalam seleksi model pendidikan terakhir (V3) dengan variabel untuk menentukan model terbaik diperoleh diperoleh model terbaik adalah : IPK (V12) dengan signifikansi $0,021<\alpha$ $=0,05$ (lihat Tabel 10).

. Dalam uji asosiasi parsial,

ditemukan adanya interaksi antara variabel

Tabel 10. Hasil Uji Parsial Antara Pendidikan Terakhir dengan Tutorial on-line dengan IPK

Partial Associations

\begin{tabular}{|c|c|c|c|c|}
\hline \\
\hline Effect & $\mathrm{df}$ & $\begin{array}{l}\text { Partial Chi- } \\
\text { Square }\end{array}$ & Sig. & $\begin{array}{l}\text { Number of } \\
\text { Iterations }\end{array}$ \\
\hline VAR00003*VAR00011 & 3 & 3.711 & .294 & 2 \\
\hline VAR00003*VAR00012 & 3 & 9.703 & .021 & 2 \\
\hline VAR00012*VAR00011 & 9 & 4.627 & .866 & 2 \\
\hline VAR00003 & 1 & 53.350 & .000 & 2 \\
\hline VAR00012 & 3 & 130.107 & .000 & 2 \\
\hline VAR00011 & 3 & 221.747 & .000 & 2 \\
\hline
\end{tabular}

Sumber : Data Diolah

Data menunjukkan mahasiswa UT dengan pendidikan terakhir SLTA dan tidak pernah mengikuti tutorial online memiliki IPK $<2$, dan sedangkan mahasiswa dengan pendidikan terakhir D1,D2,D3 dan tidak pernah mengikuti tutorial online memiliki IPK 2,76-3,00.
Hasil ini sesuai dengan penelitian Yuliawan (2011) yang menemukan adanya hubungan antara latar belakang pendidikan dengan prestasi belajar mahasiswa di Akademi Keperawatan Patria Husada Surakarta. 


\section{P. Hubungan Antara Status R. Hubungan Antara Status \\ Pernikahan Dengan Alasan Masuk UT Dengan IPK \\ Pernikahan Dengan Cara Belajar Dengan IPK}

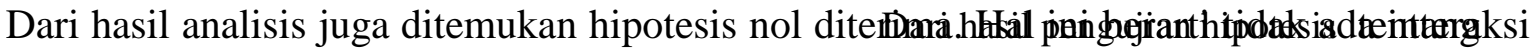

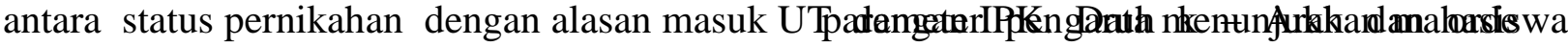

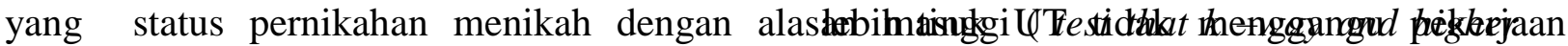
memiliki IPK <2, mahasiswa yang status pernikabadebelaffecmenikrah denganualaskan manisitkeIUT tidak menggangu pekerjaan juga memiliki IPK <Status Pernikahan, Cara Belajar di UT, dan IPK, terlihat pada Tabel 11 bahwa pada

\section{Q. Hubungan Antara Status Pernikahan Dengalinujuan Masuk UT Dengan IPdiperoleh}

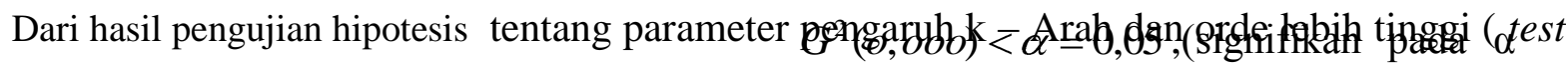
that $k$-way and higher order effects are zero) untuk 0 , (95j) yel Status Pernikahan ,Tujuan Masuk

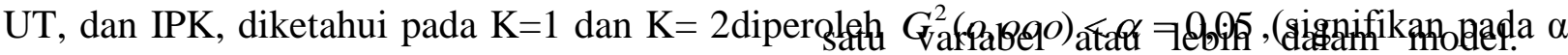
$=0,05)$ yang berarti ada efek interaksi satu variabel atau lebih dalam model. Selanjutnya, dalam seleksi model untuk menentukan model terbaik diperoleh diperoleh model terbaik adalah $\log e_{i j k}=U+U_{1(i)}+U_{2(j)}+U_{3(k)}+U_{13(i k)}$

- Dalam uji asosiasi parsial, ditemukan adanya interaksi antara variabel Status Pernikahan dengan variabel IPK dengan signifikansi $0,012<\alpha=0,05$

Tabel 11. Uji K-Arah Hubungan Antara Status Pernikahan, Cara Belajar, dan IPK K-Way and Higher-Order Effects

K-Way and Higher-Order Effects

\begin{tabular}{lcrrrrrr}
\hline & \multicolumn{6}{c}{ Likelihood Ratio } & \multicolumn{2}{c}{ Pearson } & \multirow{2}{*}{ Number of } \\
& K & df & Chi-Square & Sig. & Chi-Square & Sig. & Iterations \\
K-way and Higher $_{\text {Order Effects }}{ }^{\mathrm{a}}$ & 1 & 31 & 223.788 & .000 & 247.623 & .000 & 0 \\
& 2 & 24 & 24.460 & .436 & 42.650 & .011 & 2 \\
K-way Effects $^{\mathrm{b}}$ & 3 & 9 & 5.285 & .809 & 5.065 & .829 & 3 \\
& 1 & 7 & 199.328 & .000 & 204.972 & .000 & 0 \\
& 2 & 15 & 19.175 & .206 & 37.585 & .001 & 0 \\
& 3 & 9 & 5.285 & .809 & 5.065 & .829 & 0 \\
\hline
\end{tabular}

Sumber : Data Diolah 
Selanjutnya, dalam seleksi model diperoleh model terbaik adalah :

untuk menentukan model terbaik diperoleh

$\log e_{i j k}=U+U_{1(i)}+U_{2(j)}+U_{3(k)}+U_{23(j k)}$

- Dalam uji asosiasi parsial, ditemukan adanya interaksi antara variabel cara belajar (V9) dengan variabel IPK

(V12) dengan signifikansi $0,048<\alpha=$ 0,05 (lihat Tabel 12).

Tabel 12. Hasil Uji Parsial Antara Status Pernikahan dengan Cara Belajar dengan IPK

Partial Associations

\begin{tabular}{lrrrr}
\hline & \multicolumn{2}{c}{ Partial Chi- } & \multicolumn{2}{c}{ Number of } \\
Effect & df & \multicolumn{1}{c}{ Square } & Sig. & Iterations \\
VAR00005*VAR00012 & 3 & 1.097 & .778 & 2 \\
VAR00005*VAR00009 & 3 & .824 & .844 & 2 \\
VAR00012*VAR00009 & 9 & 17.018 & .048 & 2 \\
VAR00005 & 1 & 1.493 & .222 & 2 \\
VAR00012 & 3 & 130.107 & .000 & 2 \\
VAR00009 & 3 & 67.729 & .000 & 2 \\
\hline
\end{tabular}

Sumber : Data Diolah

\section{S. Hubungan Antara Status}

\section{Pernikahan Dengan Tutorial Tatap}

Muka Dengan IPK

Dari hasil analisis juga ditemukan hipotesis nol diterima. Hal ini berarti tidak ada interaksi antara status pernikahan dengan tutorial tatap muka dengan IPK.

\section{T. Hubungan Antara Status Pernikahan dengan Tutorial Online dengan IPK}

Dari hasil analisis juga ditemukan hipotesis nol diterima. Hal ini berarti tidak ada interaksi antara status pernikahan dengan tutorial tatap on-line dengan IPK.

\section{U. Hubungan Antara Tempat Tinggal dengan Alasan Masuk UT dengan IPK}

Dari hasil analisis juga ditemukan hipotesis nol diterima. Hal ini berarti tidak ada interaksi antara tempat tinggal dengan alasan masuk UT dengan IPK.

\section{Hubungan Antara Tempat Tinggal Dengan Tujuan Masuk UT Dengan IPK}

Dalam pengujian hipotesis tentang parameter pengaruh $\mathrm{k}$ - Arah dan orde lebih tinggi ( test that $\mathrm{k}$-way and higher order effects are zero), diperoleh nilai likelihood ratio chi square adalah 0,000. Karena $G^{2}(o, o o o)<\alpha=0,05$, maka tolak

Penerapan Uji Statistik Model Log-Linear Dalam Menganalisis -24 
H0 yang berarti ada efek interaksi satu variabel atau lebih dalam model. Dalam seleksi model untuk menentukan model terbaik diperoleh $G^{2}<\chi_{(9 ; 5 \%)}^{2}$ maka H0 diterima, hal ini berarti model $\log e_{i j k}=U+U_{1(i)}+U_{2(j)}+U_{3(k)}+U_{13(i k)}$ adalah model terbaik. Dalam uji asosiasi parsial, diperoleh nilai statistik Khi Kuadrat parsial sebesar 8.942 dengan df 3 dan sig $=0,030$, karena nilai sig $(0,030)<$ 0,05, maka hipotesis nol ditolak. Hal ini berarti ada hubungan dan interaksi antara tempat tinggal dengan IPK.

\section{W. Hubungan Antara Tempat Tinggal Dengan Cara Belajar Dengan IPK}

Dalam pengujian hipotesis tentang parameter pengaruh $\mathrm{k}$ - Arah dan orde lebih tinggi ( test that $\mathrm{k}$-way and higher order effects are zero), diperoleh nilai likelihood ratio chi square adalah 0,000. Karena $G^{2}(o, o o o)<\alpha=0,05$, maka tolak H0 yang berarti ada efek interaksi satu variabel atau lebih dalam model. Dalam seleksi model untuk menentukan model terbaik diperoleh $G^{2}<\chi_{(9 ; 5 \%)}^{2}$ maka $\mathrm{H} 0$ diterima, hal ini berarti model 2 adalah model terbaik. Dalam uji asosiasi parsial, diperoleh nilai statistik Khi Kuadrat parsial sebesar 15,903 dengan df 9 dan sig = 0,069, karena nilai sig $(0,069)>0,05$, maka hipotesis nol diterima. Hal ini berarti tidak ada hubungan dan interaksi antara tempat tinggal dengan cara belajar dengan IPK.

\section{Hubungan Antara Tempat Tinggal Dengan Tatap Muka Dengan IPK}

Dalam pengujian hipotesis tentang parameter pengaruh $\mathrm{k}$ - Arah dan orde lebih tinggi ( test that $\mathrm{k}$-way and higher order effects are zero), diperoleh nilai likelihood ratio chi square adalah 0,000. Karena $G^{2}(o, o o o)<\alpha=0,05$, maka tolak H0 yang berarti ada efek interaksi satu variabel atau lebih dalam model. Dalam seleksi model untuk menentukan model terbaik diperoleh $G^{2} \leq \chi^{2}{ }_{(9 ; 5 \%)}$ maka $\mathrm{H} 0$ diterima, hal ini berarti model $\log e_{i j k}=U+U_{1(i)}+U_{2(j)}+U_{3(k)}+U_{23(j k)}$ adalah model terbaik. Dalam uji asosiasi parsial, diperoleh nilai statistik Khi Kuadrat parsial sebesar 8,138 dengan df 3 dan sig $=0,043$, karena nilai sig $(0,043)<$ 0,05, maka hipotesis nol ditolak. Hal ini berarti ada hubungan dan interaksi antara tempat tinggal dengan tutorial tatap muka. Mahasiswa yang tempat tinggalnya jauh dari lokasi UPBJJ Medan kemungkinan memiliki kendala untuk mengikuti tutorial tatap muka. 


\section{Y. Hubungan Antara Tempat Tinggal Dengan Tutorial Online Dengan IPK}

Pengujin hipotesis tentang parameter pengaruh $\mathrm{k}$ - Arah dan orde lebih tinggi ( test that $\mathrm{k}$-way and higher order effects are zero), diperoleh nilai likelihood ratio chi square adalah 0,000. maka $G^{2}(o, o o o)<\alpha=0,05$, maka tolak H0 yang berarti ada efek interaksi satu

$$
\log e_{i j k}=U+U_{1(i)}+U_{2(j)}+U_{3(k)}+U_{12(i j)}+U_{13(i k)}+U_{23(j k)}+U_{123(i j k)}
$$

adalah model terbaik. Dalam uji asosiasi parsial, diperoleh nilai statistik Khi Kuadrat parsial sebesar 13,608 dengan df 3 dan $\operatorname{sig}=0,003$, karena nilai sig

\section{KESIMPULAN DAN SARAN}

Berdasarkan hasil analisa log linier dapat diambil kesimpulan sebagai berikut:

1. Pada hubungan Antara Jenis Kelamin, Cara Belajar, IPK ditemukan ada interaksi antara jenis kelamin * IPK dan Cara belajar * IPK, sehingga model terbaiknya adalah

$\log e_{i j k}=U+U_{1(i)}+U_{2(j)}+U_{3(k)}+U_{13(i k)}+U_{23(j k)}$ adalah variabel atau lebih dalam model. diperoleh nilai likelihood ratio chi square adalah 0,000. Karena $G^{2}(o$, ooo $)<\alpha=0,05$, maka tolak $\mathrm{H} 0$ yang berarti ada efek interaksi satu variabel atau lebih dalam model. Dalam seleksi model untuk menentukan model terbaik diperoleh $G^{2}=\leq \chi_{(9 ; 5 \%)}^{2}$ maka H0 diterima, hal ini berarti model
$(0,003)<0,05$, maka hipotesis nol ditolak. Hal ini berarti ada hubungan dan interaksi antara tempat tinggal dengan IPK. dan interaksi cara belajar *IPK, sehingga model terbaiknya adalah

$\log e_{i j k}=U+U_{1(i)}+U_{2(j)}+U_{3(k)}+U_{23(j k)}$

3. Pada hubungan Antara Pendidikan Terakhir, Alasan Masuk UT, IPK ditemukan ada hubungan dan interaksi antara Pendidikan terakhir* alasan masuk UT, sehingga model terbaiknya

$$
\log e_{i j k}=U+U_{1(i)}+U_{2(j)}+U_{3(k)}+U_{12(i j)}
$$

2. Pada hubungan antara usia, cara

4. Pada Hubungan Antara Pendidikan belajar, IPK ditemukan ada hubungan Terakhir, Tutorial Online, IPK ditemukan ada hubungan dan interaksi

Penerapan Uji Statistik Model Log-Linear Dalam Menganalisis -26 
antara Pendidikan terakhir* IPK, sehingga model terbaiknya adalah

$\log e_{i j k}=U+U_{1(i)}+U_{2(j)}+U_{3(k)}+U_{13(i k)}$

5. Pada hubungan status Pernikahan, Tujuan Masuk UT, IPK ditemukan ada hubungan dan in $\log e_{i j k}=U+U_{1(i)}+U_{2(j)}+U_{3(k)}+U_{12(i j)}+U_{13(i k)}+U_{23(j k)}+U_{123(i j k)}$ teraksi antara status pernikahan* IPK, sehingga model terbaiknya adalah

$\log e_{i j k}=U+U_{1(i)}+U_{2(j)}+U_{3(k)}+U_{13(i k)}$

6. Pada hubungan status Pernikahan, Cara Belajar, IPK ditemukan ada hubungan dan interaksi antara cara belajar*IPK, sehingga model terbaiknya adalah

$\log e_{i j k}=U+U_{1(i)}+U_{2(j)}+U_{3(k)}+U_{23(j k)}$

7. Pada hubungan Tempat Tinggal, Tujuan Masuk UT, IPK ditemukan ada hubungan dan interaksi antara tempat tinggal*IPK, sehingga model terbaiknya adalah

$\log e_{i j k}=U+U_{1(i)}+U_{2(j)}+U_{3(k)}+U_{13(i k)}$

8. Pada hubungan Tempat Tinggal, Tatap Muka, IPK ditemukan Ada hubungan dan interaksi antara tempat tinggal* tatap muka, sehingga model terbaiknya adalah $\log e_{i j k}=U+U_{1(i)}+U_{2(j)}+U_{3(k)}+U_{23(j k)}$

9. Pada hubungan Tempat Tinggal, online , IPK ditemukan Ada hubungan dan interaksi antara tempat tinggal* online*IPK, sehingga model terbaiknya adalah

SARAN

1. Kepada mahasiswa UT, agar belajar lebih serius dan semakin dapat meningkatkan motivasi belajar mandiri sehingga dapat meningkatkan IPK

2. Kepada Universitas Terbuka, agar dapat membuka program-program yang dapat mendorong kesadaran mahasiswa untuk dapat memanfaatkan fasilitas belajar yang disediakan Universitas Terbuka.

3. Kepada peneliti selanjutnya, dikarenakan dalam penilitian ini sampel penelitian hanya mahasiswa non-pendas, maka peneliti menyarankan kepada peneliti selanjutnya untuk dapat meningkatkan jumlah sampel kepada seluruh mahasiswa Universitas Terbuka dari seluruh program yang ada. 


\section{DAFTAR PUSTAKA}

Agresti, A.(1990). Categorical Data Analysis. New York: John Wiley \& Sons

Arifin, P. (2012). Hubungan Kebiasaan Belajar dan Prestasi Belajar Siswa Kelas XII B SMP Negeri 13 Malang. Skripsi. http://jurnalonline.um.ac.id/data/artikel /artikel9ECAE100E8D6949EE8D57 DD100367277.pdf

Arifudin. (2009). Hubungan antara Motivasi dengan Prestasi Belajar Siswa pada Mata Pelajaran Geografi di kelas XI IPS SMA Negeri $2 \quad$ Singaraja. http://lambitu.wordpress.com/2009/1 $0 / 28 /$

Brahmantyo, M. (2003). Analisis Statistik Faktor-faktor yang Mempengaruhi Prestasi Akademik Mahasiswa Pascasarjana ITS. http://digilib.its.ac.id/

Degeng. (2011). “ Karakteristik Belajar Mahasiswa di Berbagai Perguruan Tinggi di Indonesia". www.tp.ac.id/dok/

Fadloli. (2011). Tutorial Model Program Akreditasi Tutor I (PAT-UT) I dan Student Team Achievement Division (STAD) ditinjau dari Motivasi Belajar Mahasiswa. Jurnal Pendidikan Terbuka dan Jarak Jauh, 12(2), 133-144. Jakarta: Universitas Terbuka

Fiendberg, SE. (1976). Analysis of Cross Classification Categorical Data. London: the Mits Press
Hidayati, Y. ( 2012). Pengaruh Cara Belajar terhadap Prestasi Belajar Siswa Kelas XII Jurusan Pemasaran pada Mata Diklat Melaksanakan Proses Administrasi Transaksi di SMK Taman Siswa Sumpiuh Tahun Pelajaran 2011/2012. Oikonomia Vol.2, No. 1, ejournal.umpwr.ac.id/index.php/oiko nomia/.../394

Irawan, P.(1997). Teori Belajar, Motivasi, dan Keterampilan Mengajar. Jakarta: Depdiknas.)

Jeansonne, A (1997). " Log Linear Models".

http://www.education.umd.edu /

Pakpahan, S.P. (2004). Persepsi Mahasiswa UPBJJ-UT Medan tentang pelayanan Akademik dan Non-Akademik yang diberikan oleh UPBJJ-UT Medan. Jurnal Pendidikan Terbuka dan Jarak Jauh, 5( 1), 47-58. Jakarta: Universitas Terbuka

Mc. Clelland, A. (1987). Мemacu Masyarakat Berprestasi. Terjemahan oleh Siswo Suyanto. Jakarta: CV Intermedia.

Nasution, F. (2001). Hubungan Metode Mengajar Dosen, Keterampilan Belajar, Sarana Belajar dan Lingkungan Belajar dengan Prestasi Belajar Mahasiswa. Jurnal Ilmu Pendidikan, 8 (1)

Pujiti, S.A. (2008). "Penerapan Model Tabel Kontingensi dan Model Log Linear untuk Mengetahui Hubungan Antara Status Sekolah, Jumlah Guru erpendidikan S1 dan Angka 
Mengulang pada siswa SD ". http://blog.its.ac.id/

Reksowardoyo. (1983). Hubungan beberapa karakteristik warga masyarakat Desa Sarampad Kabupaten Cianjur dan persepsi mereka tentang ternak kelinci. Karya Ilmiah. Bogor: Fakultas Peternakan Institut Pertanian Bogor

Rosalia, S.A. dkk. (2011). "Analisis Model Log Linear untuk Mengetahui Kecenderungan Perilaku Anak Jalanan Binaan di Surabaya (Kasus Khusus Yayasan Arek intang)" http://digilib.its.ac.id/

Saifuddin, A.(1996). Pengantar Psikologi Intelegensi.Jogyakarta: Pustaka Pelajar

Saifuddin, A. (1997). Reliabilitas dan Validitas. Yogyakarta : Pustaka Balajar Offset.

Sardiman, A.M. (2001). Interaksi dan Motivasi Belajar Mengajar. Jakarta: PT.Raya Grafindo Persada

Siregar, H. (2002). Hubungan Karakteristik Mahasiswa Universitas Terbuka Program Studi Statistika Terapan dengan Hasil Ujian Matakuliah Komputer II. http://digilib.itb.ac.id/

Steel, R.G.D, and J.H. Torrie.(1995). Prinsip dan Prosedur Statistika. Jakarta: Gramedia Pustaka Utama

Yuliawan, A. (2011). Hubungan antara Motivasi Belajar dan Latar Belakang Pendidikan dengan Prestasi Belajar Mahasiswa di Akademi Keperawatan Patria Husada Surakarta. http://pasca.uns.ac.id/ 